\title{
The Trant Family (continued)
}

\section{Author(s): S. M.}

Source: Kerry Archaeological Magazine, Vol. 3, No. 13 (Oct., 1914), pp. 20-38

Stable URL: http://www.jstor.org/stable/30022075

\section{Accessed: 24-06-2016 01:43 UTC}

Your use of the JSTOR archive indicates your acceptance of the Terms \& Conditions of Use, available at

http://about.jstor.org/terms

JSTOR is a not-for-profit service that helps scholars, researchers, and students discover, use, and build upon a wide range of content in a trusted digital archive. We use information technology and tools to increase productivity and facilitate new forms of scholarship. For more information about JSTOR, please contact support@jstor.org. 


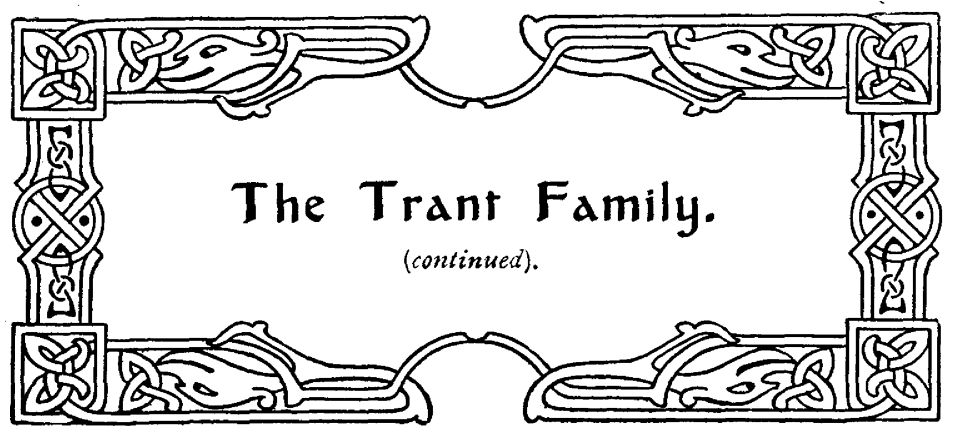

[We regret that the following paragraph was, by some mistake, omitted from the first part of this article in the magazine for April, 1914. It should have immediately followed the word "unmarried" at the end of the first paragraph on page 246, and preceded the second paragraph beginning with the words "In Burke's," \&c.]

Sir Patrick Trant is said to have had two brothers. One of them, known as "Governor"' Trant, married a sister of Sir Richard Steele, and had a daughter who married Richard 4th Earl of Cavan (who died in 1741). So it appears from Burke's Peerage, where it is stated that the Earl married "Margaret, daughter of Governor Trant, and niece of Sir Richard Steele." Lodge states that the marriage took place whilst the Earl was at Barbadoes on military service, and speaks of Governor Trant as being a brother of Sir Patrick. It is stated in a pedigree of the Steeles in the "Miscellanea Genealogica" for November, 1874, that Governor Trant married Mary née Scurlock, widow of Steele, but this is impossible, as all biographies of Steele show that he outlived her, who was his second wife, and who died in 1718. Equally erroneous is Miss Hickson's statement that Governor Trant married a daughter of Steele's. Why he was called "Governor"' Trant is not known. He may at some time have been Governor, or Acting Governor, of one of the West India Islands. In reply to a reference lately made to the Colonial Secretary at Barbadoes, we were informed that 
there was no record of any one named Trant having held either of these positions in that island. Still we cannot help thinking that, if not in Barbadoes, he must have held either that or some other important position elsewhere in the West India Islands.

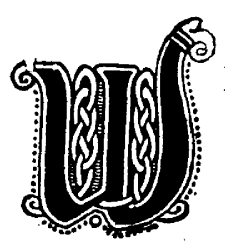

E have already suggested the probability of John, the son of Richard of Barbadoes, who made a large claim on the estate of Sir Patrick Trant, being the father of Dominick the elder. Under a deed dated the 16th Sept., 1719, Edward Rice, of Mount Rice, let to Marcus Rice, of Cork, for 31 years, the lands of Ballybowler, Ballyristeen, Ballybeg, part of Glinns held by Peter Rice, Ballycunneen, Reisk, Farranakilla, Ballyeighter, Kildrum, and his moiety of Cahir Trant, provided, amongst other things, that John Trant and Ellinor, his wife, should hold Ballyeighter, Balleyn, and Kildrum for 31 years, or as long as one of them lived. These were the same lands that were, in 1748, demised by Stephen Rice, of Mount Rice, to Dominick Trant. John Edward Rice, the lessor of 1719, was the father of Mary, who married three times, her third husband being Dominick of Dunkettle.

We take this opportunity to correct an error, in the first part of this article, in regard to the causes which led Dominick Trant (John) to overlook in his will the claims of his elder son. After further inquiry and perusal of certain documents, we now find that James Trant's religion had nothing to do with his disinheritance, which, in reality, was owing solely to the fact that he, with his half-brother Henry Goold, had entered the French service. It should be mentioned that Henry Trant's daughter, Catherine, first, in 1716, married John Gould, by whom she had two sons, Thomas and Henry, above mentioned. He died in 1729, and she married, secondly, Dominick Trant John, by whom she was the mother of James and Dominick.

Before finally taking leave of Sir Nicholas and his branch 
of the family, we wish to mention a few facts. We have stated, at page 245 supra, that Sir Nicholas' grandfather, Dominick of Ballinlea, was son of Peter Trant, who died in 1715 (younger brother of a Dominick who had died s.p. in 1688), and married a daughter of Edward Ferriter. By her he had, beside Thomas, his eldest son (Sir Nicholas' father), two others, namely, Peter, who left an only child, Ellen, living single in 1782, and Dominick, and at least three daughters:-(1) Joan, who married Blaise Moriarty of Dingle, (2) Ellen, who in 1743, married John Hickson, by whom she was great grandmother of Miss Mary Agnes Hickson, a lady distinguished for her learned writings and researches in Kerry History, embodied in "Old Kerry Records" (her best known work), and in an immense number of letters in the "Kerry Evening Post." Miss Hickson died in April, 1889, aged 73 years. (3) Margaret, who married Patrick Creagh, Esq., and had a daughter, Elizabeth, who in 1787, married Daniel Mahony of Dunloe.

We also stated that none of the descendants of James, the brother of Peter and Sir Nicholas Trant, could be traced. We have since, however, discovered one of them in the person of Captain William Trant Chambers of the Royal Field Artillery. It appears that James' daughter, Anna Maria,, married a Captain Payne, R.N. Their daughter Joanna, in 1835, married William Chambers, J.P. and D.I. of Hafod, in the County of Cardigan, whose grandson is the officer above referred to. A daughter of William Chambers married Sir Godfrey Thomas, Bart., father of the present Colonel Sir Godfrey V. Thomas, who is also, consequently, a descendant of James Trant.

We now give a pedigree of the descendants of Sir Nicholas Trant:- 


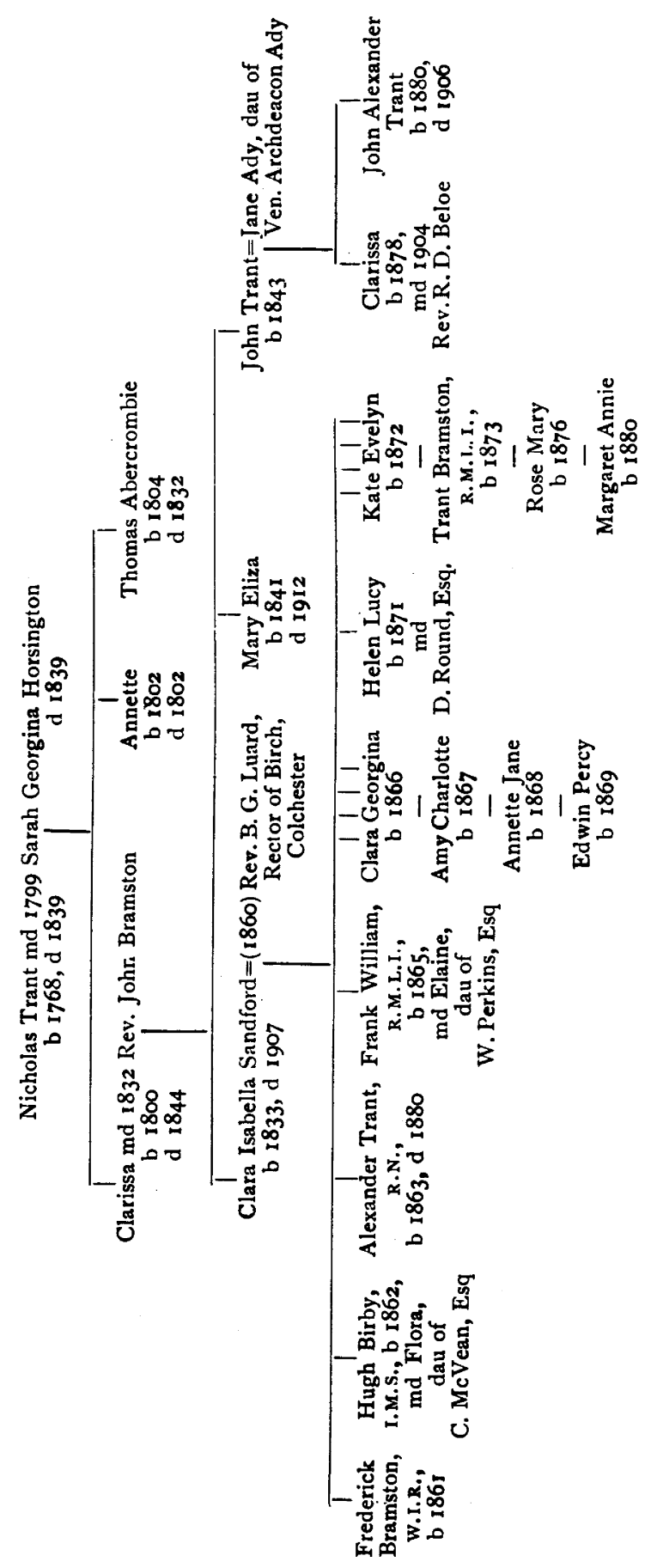


We have seen from the pedigree of Henry Trant's descendants already given, that his daughter Elizabeth married James Trant of Castleisland. The latter belonged to a separate branch of the family, who seem to have owned property at or near that place. We are unable to say how they were related to the other Trants. From a Chancery Bill, filed on the 10th November, 1692, by James Trant of "the Island of Kerry," against Francis Newton of Ventry, we see that certain moneys realised by Mrs. Skiddy (the wife of an officer of King James' army who had gone to France with Lord Mountcashel) by sale of her cattle, was handed over to James to apply it in payment of a debt due by Skiddy to Sir Patrick Trant. This may perhaps point to some relationship between him and Sir Patrick. Under a deed dated the 10th October, 1711, Randal MacCarthy More of Pallice, let to James Trant of Castleisland, the lands of Drumhumper near Killarney, and Dromin and Ards, in the parish of Aghadoe, then part of the dower of Dame Honoria, the mother of the former, and widow of Charles MacCarthy More. Then there was some litigation in 1715, and subsequently between this James Trant and Dame Honoria and others, in connection with a rent charge on the lands of Drumhumper, which she had granted him for a debt due by her, and the name of James Trant, Junior, appears in some of the proceedings. James, Senior, was probably the son-in-law of Henry Trant, and named by him in his will of 1729 as one of his executors, and James, Junior, the person who married Miss Pierse, and whose will is dated in 1776. By her he had a son, Patrick, who was for many years in command of the Revenue cruiser "Winder," and in that capacity did excellent service.

Patrick Trant entered the service of the Revenue in 1778. ${ }^{12}$ About the year 1786 he was placed in charge of the "Winder" cruiser, which was stationed on the Kerry coast, and here for some years he led a strenuous existence,

\footnotetext{
12It appears that in 1773 certain Dingle merchants owned the brig "Unity" (Captain Patrick Trant) and he was commissioned, by them, to buy goods in Liverpool and ship them to Dingse to be sent thence to France, and other countries. The money was to be paid at the house of Thomas Trant in Cork. Was he the same person that afterwards entered the Revenue Service?
} 
waging a long and successful warfare against the smugglers. ${ }^{13}$ In 1798, while reconnoitering the French fleet in Bantry Bay, he and his vessel were captured. He was a prisoner in France for nine months, and on his release was restored to his command of the "Winder," which had been retaken during his imprisonment.

At that time Revenue vessels were often employed on naval duty, especially as transports, and in October, 1799, Trant received at Waterford, a cargo of French prisoners, for conveyance to Bristol. These, having managed to obtain and conceal a few pistols, mutinied during the voyage, and wounding several of the crew, and knocking Trant down the companion, made themselves masters of the ressel. Having vainly urged his crew to stand by him, Trant possessed himself of a musket, and with great bravery attacked the prisoners single-handed. His first shot killed the Frenchman at the helm, his second wounded another, and the rest, who seemed to have no more courage than his own crew, then surrendered. This gallant action brought him a promise of promotion, while his crew were "broke" for cowardice.

This promise, however, for many years remained unfulfilled, during which time Trant was still in the receipt of a very inadequate salary, considering his long period of gallant and zealous service. At length, in June, 1804, he reminded his departmental superiors of the promise of promotion made to him five years previously, and, sometime afterwards, was placed in command of the "Old Brown." In this situation he continued until severe rheumatism, occasioned by the hardships he had undergone in earlier life, forced him to resign. He was superannuated in February, 1809 , on his full salary of $£ 191 \mathrm{1s}$. 3 d., and settled down at Portmagee, where he spent the rest of his days.

\footnotetext{
13 Smuggling was then very rife in that part of Kerry. It was a risky calling, but a very profitable one, especially when carried on by ships ready for offence and defence, and generally superior to Revenue Cutters both in arms and speed. Wool, hides, and other commodities were exported to Normandy, Brittany and Poitou; and claret, brandy and other liquors were brought from Nantes and Bordeaux. On the arrival of these smugging brigs at Portmagee an auction was held on deck, and each lot of goods disposed of to the highest bidder, among the county gentry or small traders, who paid cash and landed their purchases in their own small bosta.
} 
Patrick Trant married Clara, daughter of Charles Geoffrey O'Connell, and had issue, one son, Patrick, born 1807, who died unmarried in 1851, and six daughters:-

(1) Catherine, b. 1805, md. 25th February, 1830, Charles McCarthy, Esq. of Springmount, Co. Cork. They had one son, Samuel Trant McCarthy, a Sub-Inspector of the Royal Irish Constabulary, who died unmarried in 1871 .

(2) Mary, b. 1809, who md. in 1828, Geoffrey O'Connell. She died in 1889. Of this marriage there was the following issue :-

1 Maurice, b. 1834, d. unmarried in 1871.

2 John, md., and died, leaving one son, Geoffrey, who md. Miss Rose Little.

3 Charles Geoffrey, now of Waterview House, Portmagee.

1 Minnie, a nun, deceased; 2 Ellén, deceased; 3 Bessie, a nun.

(3) Christina (Kitty), b. 1811, md. John O'Dowd, d.s.p.

(4) Johanna, b. 1813, md. 1842, Daniel McGillicuddy, and had two sons--(1) Frank, and (2) Valentine, now of San Francisco.

(5) Ellen, b. 1815, md. 1841, Daniel McCarthy, and had issue: (1) Samuel Trant McCarthy, J.P., D.L., now of Srugrena Abbey; (2) Daniel d. unmd. in 1887; (3) William, who md. in 1892, Harriett Bentley, and d. 1901, leaving three sons, Donal, William, and Samuel; (1) Lucy; (2) Clara, who d. young; (3) Ellen, who d. unmd., 1871 (see McCarthy Pedigree).

(6) Barbara, md. - Berry, and left a son, O'Brien Berry of Denver City, U.S.A.

He died in December, 1818, his death being announced in the following terms in a newspaper of the time:-

"On Tuesday last, in Cork, Patrick Trant of Waterview in this County, Esq., one of His Majesty's Justices of the 
Peace; a gentleman who through life supported an unblemished reputation, and whose death will long be a source of unaffected regret to all who knew and appreciated his many virtues."

Captain Patrick Trant had a sister, Bridget, who married Mr. Foley of Tralee. She died at Killarney, Sept., 1832, at the age of 87. Their eldest son, Peter, married, in 1801, Miss Purcell, and had a son, also named Peter, who married in 1838, Maria Louisa, second daughter of Edward Howley, D.L., of Belleek Castle, Co. Mayo. They had, besides two daughters (Mary, who married Samuel F. Teeling, Esq., and Clara, who married William Kelly, Esq.), a son, Edward, born 1844, who married Miss Elizabeth Webster, and had, hesides several daughters, one son, Captain Peter Trant Foley, born 1882, of Ballyard House, Tralee, the present representative of the family.

Philip Henry Trant, grandson of Philip, second son of Henry Trant, was born on the 24th Feb., 1786, and entered the Navy as a midshipman in 1799. He became a Lieutenant in 1809. There is nothing recorded about his services later than 1810, when he was a Lieutenant on board H.M. ship "Rinaldo." He married, on the 9th July, 1811, Mrs. Power, a widow, but nothing further is known about them or their descendants, if any. He had a sister Maria Anastasia who, in 1806, married Mr. Richard Martin of Ballyskeadane.

Henry Trant had a brother, Richard (will 1748), who does not appear to have left any son. He had, however, a daughter, Eleanor, who married Matthew Moriarty, and by him had two sons, Blaise and Constantine, and a daughter, Elizabeth. Blaise Moriarty (will 1775), md. Joan, daughter of Dominick Trant of Ballintlea, and had issue. Constantine Moriarty md. Catherine Rice, and had a son, Matthew, who married Eleanor Segerson (daughter of James Segerson by Clara or Clarissa, dau. of Denis Mahony of Dromore). Matthew Moriarty and Ellen Segerson had a daughter, Clarissa, who md. her second cousin, Maurice Fitzgerald, by whom she had a daughter, Catherine, who married 
Michael Gallwey of Dingle. Of this Iast-mentioned marriage there was issue two sons-Patrick Fitzgerald Gallwey, a Colonel in the Army, and Matthew Moriarty Gallwey, Colonel of the Army Medical Corps, both now deceased, and three daughters, one of whom, Anastasia, md. Captain J. R. Neligan, the other two being unmarried. Elizabeth, daughter of Matthew Moriarty and Eleanor Trant, married John Fitzgerald, and their grandson Maurice married Clarissa Moriarty, as above mentioned.

We shall now proceed to give some account of the DillonTrants, which we shall preface with the following extract from D'Alton's History of the County Dublin:-

Captain John Talbot of Belgard, having no male issue, sought for his daughter an alliance with the Dillons. In 1696 she married Thomas Dillon of Brackloon, grandson of Theobald, 1st Viscount Dillon of Costello-Gallen. His son, Henry Dillon, inherited the estate. His friends conceived that he was entitled to the Viscounty of Costello-Gallen, but though he was advised that the claim was clear, he did not proceed with it. He married one of the co-heiresses of Michael Moore, of the noble house of Drogheda (the other marrying Gerald Aylmer of Lyons, John Coppinger ${ }^{14}$ of Ballyvolane, Sir J. Bellew of Barmouth, and John, 9th Lord Cahir, respectively.

Henry Dillon, by this marriage, had two sons, Thomas and John, and two daughters, Catherine and Alicia. Thomas md. Mary Dowell, dau. of Luke Dowell of Mantua, Co. Roscommon, and secondly, Margaret O'Moore of Cloghane, (who, on his death, married Field-Marshal Count O'Brady, Grand Chamberlain to Francis II., Emperor of Austria). John was a distinguished Austrian officer. On the death of Thomas he returned home, and died in Belgard, in 1796. Catherine then became entitled to the estates. She married Dominick Trant, a descendant of the ancient family of Eastingwold, in Yorkshire. She had, by him, a son, Dominick, the younger, who md. Margaret Bellew, niece of Lord Bellew of Duleek, and had issue: Henry Dillon Trant, the present (1838) proprietor of Belgard, Ballycorney, etc., and a

14 Whose only daughter married in 1767 the 11th Duke of Norfolk. 
daughter Frances, who married General Henry Count Dillon, brother of Charles, the 12th Viscount Dillon, and by him had a son, Charles, a Colonel in the army, and a daughter, Maria, who married the Prince and Duke of Croy.

So far goes D'Alton's account of the family. It is clear, however, that there was also issue of the marriage of Dominick Trant, the younger, with Margaret Bellew, an elder son James, and other children. This is apparent from the will made in 1804 by this James Trant, who thereunder bequeathed his real estates, plantations, etc., in Montserrat, to his son, Dominick. The testator must then have been a comparatively young man. He also refers in the will to his brother, Henry, and to his "sister, Frances Dillon, wife of the Honble. Colonel Dillon," 15 and to another sister named Elizabeth. His son, Dominick, according to a note in Burke's “Extinct Baronetages," married a Miss Story, daughter of P. L. Story, Esq., ${ }^{16}$ and left a son and a daughter. The Commissioner of Montserrat, to whom we made a reference on the subject, has forwarded a report from the Sub-Inspector of Police, enclosing a copy obtained by the latter, of a certificate of the baptism on the 5th May, 1838, of Dominick, the son of Dominick Trant, Esq., and Mrs. Caroline Trant, born on the 7th March, 1838, at Rose Hill, Montserrat. The godfather is mentioned therein as Henry Trant (doubtless the boy's uncle), and the godmother, as Miss Amelia Story, probably a sister or other relative of the boys' mother. The Sub-Inspector states as follows:"Trant's Estate is called after the Trant family, who were the original owners of the property. There are no representatives of the family now in this Island, and I am unable to discover how or when they severed their connection with it." He further states that, from what he could learn, the child, whose baptismal certificate he obtained, was the only one there born to Dominick Trant, whose wife, he adds, "is

\footnotetext{
$15 \mathrm{He}$ was a brother of Count Arthur Dillon who perished during the French Revolution, and of Charles 12th Viscount Dillon.

16This was Philip Laycock Stony (2nd son of Revd. Philip Stony, of Lockington Ha'l, Leicestershire, who was born in 1782, and died in 1834, having married Lydia, sister of Alexander Baring, : st Lord Asburton. The family is now represented by Henry Valentine Stony, J.P., of Ruddington Manor, near Nottingham.
} 
said to have been a notorious gambler." The Commissioner states that the Estate called "Trants" on the eastern coast of Monserrat, is now in the possession of a Mrs. Laura Howes, widow of Seymour Wylde Howes, a coloured native of the Island, who died on the 21st October, 1892, aged 40, leaving four sons and two daughters.

Now, to go back to Henry Trant, commonly called Henry Dillon Trant (the younger brother of James Trant of Montserrat and Ryde), who succeeded to the family estates in Dublin and Roscommon. There was a grant of arms confirmed in 1816 to him, and the descendants of his grandfather, Dominick Trant, he being therein described as of "Rathmile." He survived his elder brother for 53 years, and his will bears date the 24th April, 1857 In it he bequeathes legacies to his nephews, Henry Trant and Colonel Dillon, and an annuity to his sister-in-law, Mary Trant. She may have been the widow of his brother James, who died 53 years previously, and whose name also was Mary, or perhaps the widow of another brother Dominick. In this document he also alludes to the will made in 1790 by his uncle (? grand-uncle), John Dillon, who, he states, died in 1800 . This must be the John Dillon shown in the pedigree as the brother of Catherine Dillon, who married Dominick Trant. It is stated, however, by D'Alton that he died in 1796. On the death of Henry Dillon Trant, or subsequently, some at least of his property must have come to his nephew Dominick, who was a J.P. for the Co. Roscommon. On the latter's death, some years ago the estates had to be sold to satisfy the claims of creditors. He left a niece and adopted daughter, Miss Ida Dillon Trant (the daughter of his brother Henry), to whom we are indebted for some information regarding the family. Amongst other particulars she mentioned that her grandfather, Dominick Trant, once owned some estates in Montserrat. He was probably a brother of James Trant, who made his will in 1804. On the death of Miss Dillon Trant in 1909 this Franch of the family seems to have become extinct. 
The following genealogical tree will show at a glance the pedigree of the Dillon Trants. It is stated, in Burke's Extinct Baronetage that Sir Patrick's brother, Dominick, married a sister of Sir Stephen Rice, and was ancestor of the late (1838) Dominick Trant of the Island of Montserrat, who married a daughter of P. L. Story. We also see that this last-mentioned Dominick was great grandson of the Dominick, who married Catherine Dillon, who must have been a son of the Dominick, who married Sir Stephen Rice's sister.

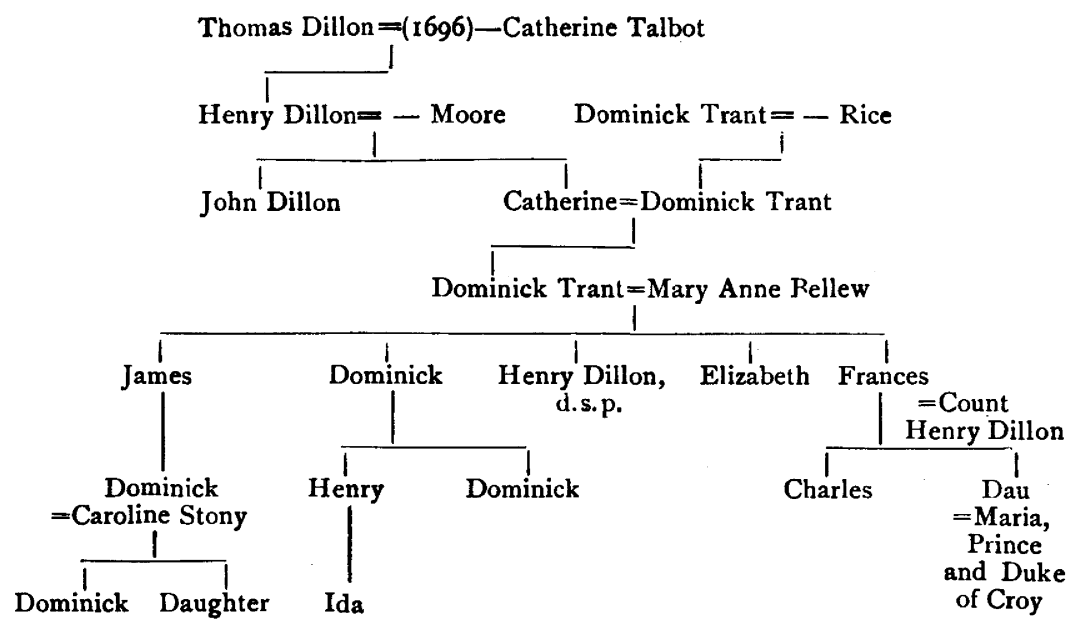

The above branch of the family appears to have been connected with, and owned property in, Montserrat since the end of the 17th century. There were also then a good many Trants settled in the Island of Antigua, all probably related. We find from Vere Oliver's History of Antigua that in $1698 \mathrm{Mr}$. Garrett Trant of Montserrat, Mr. David Rice, and Mr. Thomas Trant, junior, of London, were appointed by William Bridges (holding in trust the Garden Grove for Mr. Thomas Trant, a Roman Catholic) to sell or let that estate, and that two of them accordingly granted a lease of it for 99 years to Mr. Daniel MacKinnon. In 1792, Callaghan McCarthy bought it from Mr. William 
MacKinnon. Martin French of Montserrat, in his will made in 1724, alludes to his friend Dominick 'Trant, then about to settle as a merchant. In the Montserrat census papers of 1729-30, we find the name of a "Dominick Trant, Esquire, Counsellor.' In 1742 Martin Blake, of St. Kitt's, married Sarah, daughter of Dominick Trant of Montserrat. He died the following year, but she was living in 1760 in Paris. In his will, made in 1762, Dominick Trant, of "Montserrat and London," bequeathed sums of money to his daughter, Sarah Blake, his son James, and his grandson, Dominick Henry Trant. His son James must have died soon after this, as we find that in the same year admmistration of his estate was taken out by his sister, Sarah Blake, as guardian of the deceased's only child, Dominick Henry. Then again, by a deed dated 6th October, 1775, Dominique Henri Trant and Sarah Blake conveyed an estate called "Trant's Estate", in St. Kitts in trust to Sir R. Neave and John Willet. There is recorded the death, on the 10th December, 1803, of Dominick James Trant, Esquire.

Now all those Trants we have just referred to must have been distinct from those mentioned in the Dillon-Trant pedigree, above given, as descended from Sir Patrick's brother, Dominick, though possibly more or less nearly related to them. They may have sprung from another son of his. It is clear that there must have been at least two families of Trants settled in those days at Montserrat. Dominick Trant of Dunkettle appears to have been related to one of them at all events. He speaks in his diary of having met his "relative," Mr. Trant of Montserrat, in September, 1871, at Stenay, in Lorraine, and, from one of his letters, it appears that he was in receipt of a considerable income as his share of the profits of the Montserrat estate.

There is also recorded the marriage, at St. Luke's Church, Chelsea, in 1798, of James Trant of Montserratt to a Miss Barrett. This is, of course, the James Trant whose name is set forth in the pedigree as the son of Dominick Trant and Mary Bellew, and who made his will in 1804, being then at Ryde in the Isle of Wight. It would seem from this and other things mentioned in the course of the 
above remarks, that the Trants settled and owning estates in the West Indian Islands, even in the 18th century, kept well in touch with their kinsfolk at home, and visited their mother country more frequently than one might have supposed feasible at a time when rapid steam communication did not exist.

Allusion has already been made to the will made in 1684 by Richard Trant of Barbadoes appointing his kinsman Patrick (supposed by some to be Sir Patrick) as executor for his only. son John, and Thomas Trant and others of Barbadoes as overseers. In January, 1699, Patrick having died, a commission was issued to Thomas to finish the administration; and in 1701 the latter too being dead, the administration devolved on his widow, Mrs. Ann Trant. This lady, in 1706, had Colonel John Rice arrested for $£ 1,452$, due on Army debentures. It seems that Colonel Rice, at the surrender of Limerick, induced his regiment of foot not to go to France but to join the English Army. The Lord Justices broke up his regiment on the 31st January, 1691, and seized his horses and accoutrements. He spent 15 years in trying to get his accounts paid. Being in financial difficulties, he obtained $£ 1,500$ from Mrs. Ann Trant to be invested for herself and her six small children. This was money due to her late husband, and had just been collected with much difficulty.

We received, some months ago, from the Colonial Secretary at Barbadoes, a communication giving the following particulars :-One Thomas Trant was married to Mrs. Annie Dubois ${ }^{17}$ in 1683: Richard, son of Thomas Trant, baptised 1684; Anna, daughter of Thomas, baptised 1685; Maurice Trant was buried in 1680 ; Agatha, daughter of Richard Trant, was buried in 1724, and Richard Trant was buried in 1726.

Another Trant family was that of whom Patrick Trant, once Sovereign of Dingle, was a member. He died in 1819, his death being announced as follows in a Kerry paper:"Died, on Thursday evening last, at Dingle, Patrick Trant,

17Doubtless the lady referred to. 
Esq., 'Sovereign' of that town, which important situation he discharged for some years with diligence, integrity, and honour. The literary acquirements of this gentleman were of the first order, and he was uniformly acknowledged by those who knew him best, as an honest man in all relations of life." He married Sarah, daughter of John Eagar of Coomduff, by Miss Creagh, and had at least two sons: Thomas and William, and two daughters, Mary and Ellen. Of the sons, Thomas, in 1831, married Maryanne, eldest daughter of Pierce Chute of O'Brennan, by whom he had sons. He emigrated to America. In the announcement of his marriage in the "Tralee Mercury" of the 3rd August, 1831, he is described as the "eldest" son of Patrick Trant. But his nephew, General H. T. Richmond, in a letter to the writer of this sketch, states that William was the eldest. The latter served in the Ordnance Department for several years in Ceylon. He married there a Miss Vanderspar, and died without issue.

Of Patrick Trant's daughters, the elder, Mary, married Colonel Edward Day, of the Indian Army, uncle of the late Bishop Maurice Day, of Cashel, by whom she had two sons, both officers in the Army, one of whom, an officer of the Bengal Artillery, was killed, in 1849, in the 20th year of his age, at the battle of Guzerat, when serving under Lord Gough. She had also a daughter, Sarah, who married firstly, Captain Francis Spring, of the 24th Regiment, killed in action during the Indian Mutiny in 1857, and secondly, in 1859, Thomas Morres Hamilton Jones, D.L., of Moneyglass House, Co. Antrim.

The second daughter, Ellen, married Captain Sylvester Richmond, who was an officer of the 49 th Regiment, and died a Captain of Invalids at Chelsea Hospital, in 1869, his widow following him two months after. They had a large family of sons and daughters. The eldest son, Sylvester, died in Ceylon some nineteen years ago, and, since then the second son, General Henry Thomas Richmond, a third named William, and a fourth, Colonel R. O. Richmond, have all passed away.

The only genealogical information about this family is 
a statement by Miss M. A. Hickson, that the great-grandfather of Thomas Trant, who married Mary Anne Chute, was father of Dominick Trant, of Dunkettle. If this be true, Dominick Trant must have had a sister (though no mention of such a person is made in his will, or in that of his father's) and she must have married the father of Patrick Trant, the "Sovereign." It is known that Dominick's brother, James, had no son and no daughter through whom the relationship could be established. There seems no good cause to doubt this statement of Miss Hickson, who as a rule was very accurate in these matters. It has been supposed also that Patrick Trant, the "Sovereign," was a brother of Sir Nicholas Trant, but this certainly reeds confirmation.

There was another family of Trants residing at Listowel during the 18th century. From th wills of Thomas Trant, of Listowel, dated 1763, and of his widow, Clara, made in 1790, it would appear that they had a son, Thomas, who spent some time in India; a son, Garrett, whose daughter, Margaret, married Richard Annesley Simpson, of Dublin; and a son James. Their son, Thomas, is doubtless the person referred to in the following announcement published in the "Limerick Gazette" in July, 1812:-

"Died on Tuesday last, at his house, Glanmire Road, Cork, Thomas Trant, Esq. In the course of a lengthened life, many years of which were spent in the exercise of official duties in India, he always upheld the character of an honest man."

Thomas and Clara Trant had also a daughter, Ellen, who married a Thomas Pierce; a daughter, Bridget, who married a Grady; and two others, Elizabeth and Clara. Thomas had a brother Patrick, of Castlemaine (will 1759). There is on record a deposition given by a "Patrick Trant, of Castlemaine" (probably this very person), on the 20th October, 1713, before two magistrates, i.e., John Blennerhassett, of Killorglin, and Edward Herbert of Kilcow, wherein he states that certain persons had been conveyed to France in a ship belonging to Captain Richard or Matthew Butler, from Valencia, for their education. He also gives 


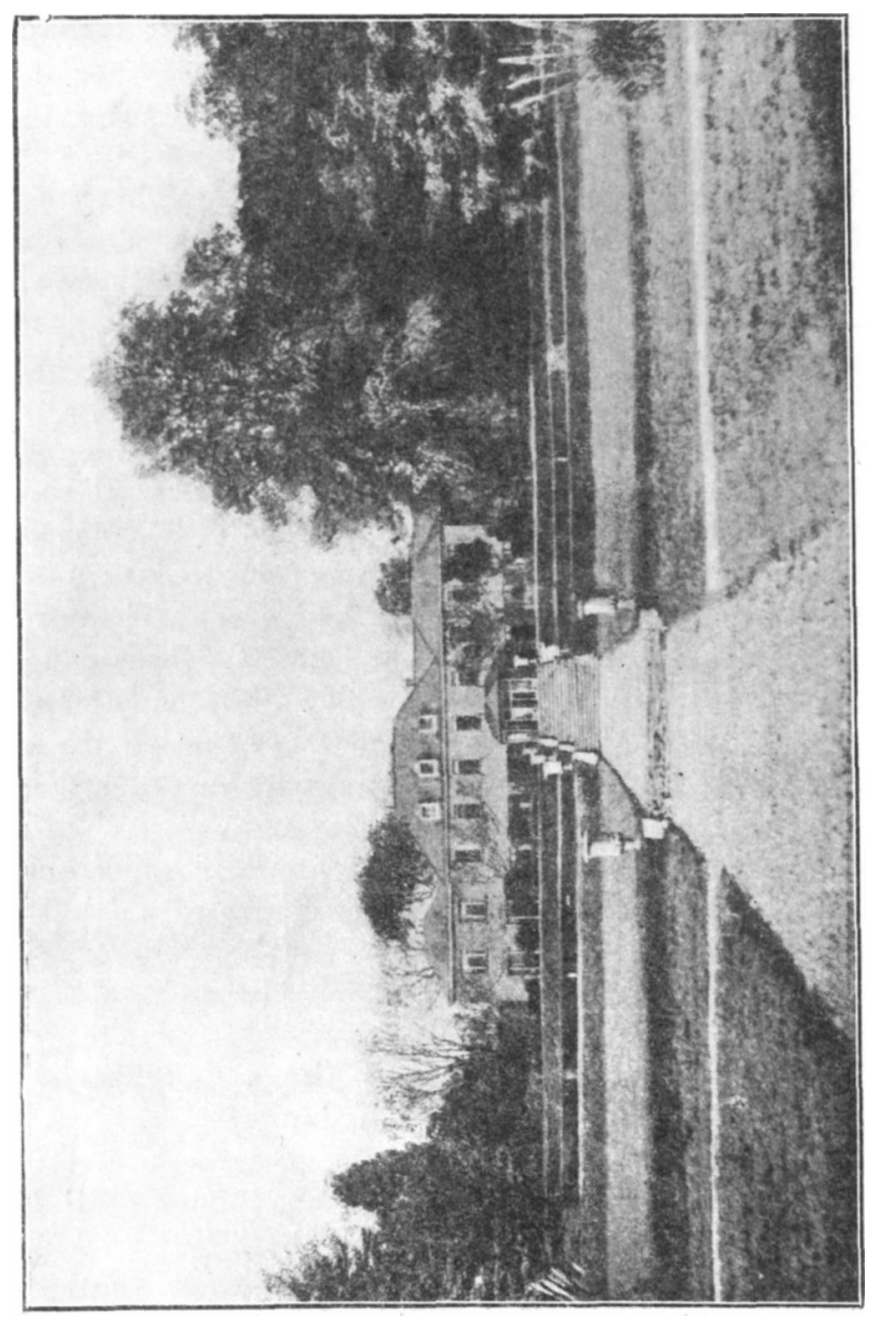

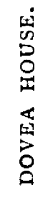
All use subject to http://about.jstor.org/terms 
information about breaches of the Penal Laws then in force. Dominick Trant (John) in his will of 1755, names Michael Trant of Castlemaine, as a contingent inheritor of his estate.

Clara Trant, in her will, speaks of her "nephew Dominick of Dublin," whom she makes her sole executor, and to whom she says her son, Thomas, had remitted portion of a sum of $£ 500$ from India. This was in all probability, Dominick, formerly of Dunkettle, and then residing in Dublin, where he died towards the end of the same year; and, in that case, the testatrix must have been a sister of his father. The relationship of aunt and nephew, or rather nephew-in-law would, of course, have also existed, on the supposition that Dominick, the elder, and Thomas were brothers. This however is improbable, from the fact that Dominick, though mentioning Thomas as a contingent heir does not call him his brother, as he almost certainly would have done, if they were so related. In one of the papers of Dominick, junior, there is an entry of a sum of $£ 130$ received by Thomas Trant in the East India. This of course was natural enough, seeing that they were cousinsgermain.

It seems impossible now to trace out any descendants of the Listowel Trants. With them may possibly be connected another Listowel family, at present represented by the Rev. Timothy Trant and his brothers, Patrick Trant, J.P., Tournageehy, and James Trant, M.D., Waterville. They are sons of the late Patrick Trant, whose father was James, son of Patrick. Farther back we are unable to trace them.

William Trant, of Cork City, in his will made in 1725, speaks of his wife, Phillis; his sons, William, Ignatius, Edward and David; his daughter, Mary, and four younger children. He left $£ 100$ to Barbara Trant, daughter of Peter Trant, which her uncle, Garrett, had lodged with testator for her use. His executors were his brothers, Stephen Woulfe, of Tiermaclante, Co. Clare and James Power, of Cork City. The ancestry of this William Trant is not known. His son, Ignatius, was probably the person of that name recorded in Farrar's Index as having died in 
1794, and doubtless the father of Ellen Trant, who married James Fagan.

In Kerry pedigrees one occasionally comes across intermarriages with Trants. For instance, Robert Hilliard, the first of his name who settled in Ireland (circa) 1656, is mentioned as having married a Miss Trant. She is said to have been a daughter of Sir Patrick, or of his brother Governor Trant. It is clear, however that she could not have been a daughter of either.

Then a Barbara Trant, in the early part of the 18th century, married Robert Hickson, of Dingle, the direct ancestor of Colonel Robert Albert Hickson, C.B., of Ballintaggart, and also of the late S. M. Hussey, D.L., of Aghadoe House. It is not clear who she was, but she might have been the Barbara, daughter of Peter Trant, mentioned in William Trant's will of 1725, above referred to, and, if so, her father might have been the father of Dominick Trant, of Ballintlea.

It also appears that James ("Mountain") Mahony, son of James, the second son of Denis (the first) of Dromore, married a Miss Trant, but we are unable to say who she was. Possibly she was a sister of Peter and Sir Nicholas Trant.

There are some Trant families in Devonshire and Cornwall about whom we should like to obtain further information, and if so we hope at some future time to give an account of them, and possibly to add to what we have already written about the Irish Trants.

We are indebted to Mrs. Trant of Dovea, Miss Margaret Luard, Birch Rectory, Colchester, Essex, and Miss Moriarty, 35 Manor Park, Lee, London, for much valuable assistance given by them towards the preparation of this paper.

S. $\mathbf{M}$.

ERRATA-In pedigree at p. 256, No. 12 :-

For "Cauton" De la Gardie, read "Countess."

For "1876" (birth year of P. H. Trant) read "1786." 